Research Article

\title{
Relationship of prostate-specific antigen (PSA) and prostate volume in patients with biopsy proven benign prostatic hyperplasia (BPH)
}

\author{
Aulia Nur Fadila ${ }^{1}$, Anny Setijo Rahaju ${ }^{2 *}$ Tarmono $^{3}$ \\ 1) Faculty of Medicine Airlangga University \\ 2) Department of Anatomical Pathology, Faculty of Medicine Airlangga University \\ 3) Department of Urology, Faculty of Medicine Airlangga University
}

\section{A R T I C L E I N F O \\ Submitted : October 2019 \\ Accepted : February 2020 \\ Published : July 2020}

\section{Keywords:}

benign prostatic hyperplasia, prostate-specific antigen, prostate volume

\section{*Correspondence:}

anny_sr@fk.unair.ac.id

\begin{abstract}
Benign prostatic hyperplasia $(\mathrm{BPH})$ is one of the most common benign tumors in men with prevalence ranging from $50 \%$ for men in their 60 s to $90 \%$ for men in their 80 s. The researcher sought to determine the relationship of prostate-specific antigen (PSA) and prostate volume in patients with benign prostatic hyperplasia. This study was based on 33 cases of benign prostatic hyperplasia in the Department of Urology, RSUD Dr. Soetomo Surabaya that diagnosed by histopathology examination. Cases with malignancy, acute urinary retention, and prostatitis were excluded. The variables of prostate-specific antigen and prostate volume were examined. The results of this study found that 33 men were enrolled with mean PSA 16,04 ng/ $\mathrm{ml}$ and a mean prostate volume of $49,13 \mathrm{ml}$. Overall, $84,8 \%$ had PSA level $>4 \mathrm{ng} / \mathrm{ml}$ and $90,9 \%$ had prostate volume $>25$ $\mathrm{ml}$. Prostate-specific antigen has significant correlation with prostate volume $(\mathrm{p}=0,019 ; \mathrm{r}=0,362)$. This study concluded that prostate-specific antigen and prostate volume showed a significant correlation.
\end{abstract}




\section{INTRODUCTION}

Benign prostatic hyperplasia (BPH) is a histological diagnosis associated with uncontrolled proliferation of connective tissue, smooth muscle, and epithelial glands of the prostate gland resulting in increased prostate volume (Parsons \& Patel, 2014). More specifically, prostate enlargement occurs due to hyperplasia of the stromal and epithelial glands that occur in the periurethral transition zone of the prostate gland (Dhingra \& Bhagwat, 2011). This condition causes the urethra pars prostatic depressed and it will inhibit the flow of urine when emptying the bladder. Disruption of urine flow in BPH causes symptoms such as frequency, urgency, nocturia, intermittence, decreased flow, and hesitation (Kapoor, 2012).

Genetic, dietary, and lifestyle factors play an important role in the growth process of $\mathrm{BPH}$. Recent research shows that there is a strong association between clinical BPH and metabolic syndrome, erectile dysfunction, and inflammation (Lim, 2017). The incidence of BPH is very much related to age. Prostate enlargement begins when a man turns around 40 years old. The prevalence of BPH from histology shows positive results in approximately $8 \%$ of men in their 40 s, $50 \%$ in their 60s, and $80 \%$ in their 90s (Lim, 2017).

Prostate volume is an indicator of BPH and progression therapeutic response given. Transrectal ultrasonography (TRUS) is the most accurate method for assessing the shape and volume of prostate examination. The TRUS examination includes a routine examination for BPH patients (Mochtar et al., 2015).

Serum prostate-specific antigen (PSA) tests are performed for health screening and early detection of prostate cancer. PSA measurement should be performed only if a diagnosis of prostate cancer will change the management or if PSA can assist in decision-making in patients at risk of progression of BPH (Mochtar et al., 2015). Serum PSA is a marker of prostatic gland epithelial cell activity. Increased serum PSA levels often indicate abnormalities of the prostate (Kowalkouski, Goltz, Hart, \& Latini, 2013). This shows that in addition to prostate volume, serum PSA also has a relationship with $\mathrm{BPH}$ in terms of predicting progression. Much research has been done in various countries regarding the relationship between PSA and prostate volume, but not many similar studies have been done in Indonesia, especially in Surabaya. Our research aims to analyze the relationship between serum PSA and prostate volume in patients diagnosed with $\mathrm{BPH}$ through histopathological examination.

\section{METHODS}

This study was an observational analytic study with a cross-sectional approach conducted in the case of BPH at the Urology Polyclinic Dr. Soetomo Surabaya in January 2017 December 2018. The inclusion criteria of this study were: (1) BPH was diagnosed based on histopathological examination results, (2) data on the results of PSA examination in medical records and (3) data on the results of the TRUS examination was recorded in medical records. Patients diagnosed with BPH with malignancy, acute urinary retention and / or prostatitis were excluded from the study data.

Serum PSA samples of patients were processed using ADVIA-Centaur XPT by the direct chemiluminometric method in the Clinical Pathology laboratory of Dr. RSUD Hospital Soetomo Surabaya. The prostate volume calculation formula used is a prolate ellipsoid. The formula used to calculate prostate size is height (anteroposterior) x width (transversal) $\mathrm{x}$ length (cephalocaudal) $\mathrm{x}(\pi / 6)$ (Haverkamp et al., 2019). Determination of the relationship between serum PSA and prostate volume using 
the Spearman statistical test with statistical analysis was significant when $p<0.05$. This study has received ethical approval from the Health Research Ethics Committee Dr. Soetomo Surabaya (0620 / KEPK / IX / 2018).

\section{RESULTS}

Samples were collected from 33 patients who met the inclusion and exclusion criteria. All patients were male with various age ranges. The average age, serum PSA and prostate volume are shown in Table 1.

The average age of patients diagnosed with BPH was 64.81 years (SD 7.06, age range 5380 years), $2(6.1 \%)$ were in the age range 46 55 years, $20(60.6 \%)$ were in the age range of
56 - 65 years and $11(33.3 \%)$ were in the age range $>65$ years. The relationship between age, serum PSA and prostate volume of $33 \mathrm{BPH}$ patients is summarized in Table 2.

The average serum PSA was $16.04 \mathrm{ng} / \mathrm{dl}$ (SD 6.23 , serum PSA range $2.20-80.40 \mathrm{ml}$ ). The majority of serum PSA BPH patients $(84.8 \%)>$ $4 \mathrm{ng} / \mathrm{dl}$. The average prostate volume is 49.13 $\mathrm{ml}$ (SD 18.60, volume range 14.3 - $95.7 \mathrm{ml}$ ). The majority of $\mathrm{BPH}$ patients $(90.9 \%)$ have prostate volume $>25 \mathrm{ml}$. There was a strong relationship between serum PSA and prostate volume (Spearman correlation coefficient $\mathrm{r}=$ $0.362, \mathrm{p}<0.05)$. The relationship between serum PSA and prostate volume in BPH patients are shown in Table 3.

Table 1. The main parameters of the study

\begin{tabular}{ccc}
\hline Parameter & Mean & SD \\
\hline Age & 64,81 years & 7,06 \\
PSA serum & $16,04 \mathrm{ng} / \mathrm{dl}$ & 16,23 \\
Prostate volume & $49,13 \mathrm{ml}$ & 18,60 \\
\hline
\end{tabular}

Table 2. Average research data by age group

\begin{tabular}{cccc}
\hline Age (years) & $\begin{array}{c}\text { Number of } \\
\text { patients [\%] }\end{array}$ & PSA (ng/dl) [SD] & $\begin{array}{c}\text { Prostate volume } \\
(\mathrm{ml})[\mathrm{SD}]\end{array}$ \\
\hline $46-55$ & $2[6,1]$ & $12,50[4,89]$ & $53,50[12,59]$ \\
$56-65$ & $20[60,6]$ & $18,29[18,57]$ & $53,12[18,66]$ \\
$>65$ & $11[33,3]$ & $12,59[12,63]$ & $41,08[18,00]$ \\
\hline Total & $33[100]$ & $16,04[6,23]$ & $49,13[18,60]$ \\
\hline
\end{tabular}

Table 3. Spearman correlation test between PSA levels and prostate volume

\begin{tabular}{lc}
\hline \multicolumn{1}{c}{ PSA and prostate volume correlation } & Result \\
\hline Correlation coefficient & 0,362 \\
Significance (one-tailed) & 0,019 \\
\hline
\end{tabular}




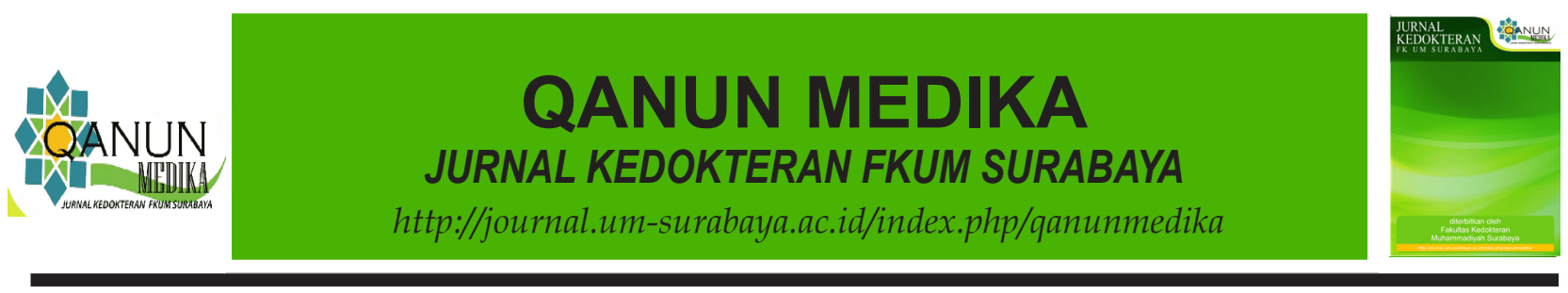

\section{DISCUSSION}

A total of 33 data from patient medical records have been verified as inclusion data from this study. This study found that the majority of BPH events occurred in the age range of 56 - 65 years, with an average age of 64.81 years. These results are consistent with research conducted by Al-Khalil et al. (2016), of the 130 BPH cases found, 86 were aged 66-69 years. Another recent study by Krisna, Maulana, \& Kresnoadi (2017) stated that the average age of BPH patients in their study was 64.32 years. These findings indicate that the risk of BPH events in men increases in old age.

This study showed that as many as $84.8 \%$ of BPH patients had PSA levels exceeding the normal limit ( $>4 \mathrm{ng} / \mathrm{dl}$ ) and the remaining $15.2 \%$ had PSA levels within the normal range $(\leq 4 \mathrm{ng} / \mathrm{dl})$. These results are consistent with the results of research conducted by Liu, Tang, Gong, \& Kong (2017) which states that BPH patients with PSA levels $>4 \mathrm{ng} / \mathrm{dl}$ are more numerous than BPH patients with PSA levels $\leq 4 \mathrm{ng} / \mathrm{dl}$ both before surgery and after surgery. Other studies that also support this result are studies by Rybalov et al. (2013) which states that 171 of the $245 \mathrm{BPH}$ patients studied had PSA levels $>4 \mathrm{ng} / \mathrm{dl}$. In another similar study conducted by Erdogan et al. (2019), the average PSA level was $9.3 \mathrm{ng} / \mathrm{dl}$ from a total of 137 BPH data obtained. Research conducted in Indonesia by Putra et al. (2016) on $1,638 \mathrm{BPH}$ patients found an average PSA level of $4.93 \mathrm{ng} / \mathrm{dl}$. This study obtained data with an average PSA level that is far different from the existing research, with a difference of about $11.1-6.73 \mathrm{ng} / \mathrm{dl}$. This difference is due to the different research methods used. In a study conducted by Erdogan et al. (2019) has exclusion criteria for PSA levels of more than $30 \mathrm{ng} / \mathrm{dl}$. In a study conducted by Putra et al. (2016) established exclusion criteria for PSA levels of more than $10 \mathrm{ng} / \mathrm{dl}$. Research conducted at RSUD Dr. Soetomo uses a different method from the research mentioned above. The difference is that in this study, there is no maximum limit of PSA levels in the exclusion criteria so that the research results obtained are not the same as the existing research.

This study showed that as many as $90.9 \%$ of BPH patients had a prostate volume exceeding the normal limit (>25 ml), and the remaining $9.1 \%$ had a prostate volume within the normal limit $(\leq 25 \mathrm{ml})$. These results are consistent with research conducted by Deori, Das, \& Rahman (2017) which states that $27.5 \%$ of BPH patients have prostate volume $\leq 30 \mathrm{ml}$, while the remaining $72.5 \%$ have prostate volume $>30 \mathrm{ml}$. The highest volume frequency distribution is in the range of $40-60 \mathrm{ml}$, as many as 13 patients $(39.4 \%)$. The average prostate volume in this study was $49.68 \mathrm{ml}$. Research conducted by Mao et al. (2009) in China stated that the average prostate volume of $268 \mathrm{BPH}$ patients was 42.45 ml. Putra et al. (2016) research in Indonesia states that the average prostate volume of 666 $\mathrm{BPH}$ patients with indwelling catheters is 47.58 $\mathrm{ml}$, while the average prostate volume of 972 $\mathrm{BPH}$ patients without indwelling catheters is $41.43 \mathrm{ml}$. The difference in the average prostate volume in BPH patients can be due to BPH risk factors that are not the same in each study. These risk factors include race (Egan, 2016), obesity (Jung et al., 2016) and diabetes (Sarma et al., 2009). The above risk factors are not mentioned Mao et al. (2009) and Putra et al. (2016) can be the cause of the difference in average prostate volume results when compared to the results of research conducted at Dr. Soetomo Hospital.

Research conducted at Dr. Soetomo Hospital Surabaya found a significant correlation between PSA levels and prostate volume in BPH patients $(\mathrm{r}=0.362 ; \mathrm{p}=0.019)$. Another study supporting this result is Putra et al. (2016), who found a correlation between PSA levels and prostate volume in the male population at Dr. RSUPN Cipto Mangunkusumo hospital $(r=0.26 ; p$ 
$=0.0001)$ of the $1,638 \mathrm{BPH}$ patients studied. Research Krisna, Maulana, \& Kresnoadi (2017) states that there is a correlation between PSA levels with the prostate volume of 0.384 ( $p$ $<0.05$ ) in BPH patients studied at Bhayangkara Hospital Mataram. Another study by Mao et al. (2009) suggested that there was a correlation between PSA levels and prostate volume $(\mathrm{r}=$ $0.278 ; \mathrm{p}<0.001)$ in 268 Chinese men with a diagnosis of $\mathrm{BPH}$.

A significant relationship between PSA levels and prostate volume, can be supported by one of the pathophysiological theories of BPH, namely the presence of epithelial-stromal interaction. Epithelial-stromal interaction plays a vital role in the hormonal, cellular, and molecular regulation of prostate development in both normal and neoplastic prostates (Tang \& Yang, 2009). The aging process causes a gradual accumulation of prostate mass as a result of ongoing prostate gland-stromal interactions, which can be increased by various growth factors that are provided systemically through circulation or locally through the urethra (Tang \& Yang, 2009). Expressions that deviate from growth factor peptides or their receptors can directly contribute to uncontrolled growth which ultimately results in BPH. Stromal cells are responsible for secreting many growth factors such as fibroblast growth factors, growth factors such as insulin I and II, and tumor growth factors, which act automatically on the stroma itself and adjacent glandular cells to induce proliferation (Tang \& Yang, 2009). The proliferation of these cells causes excessive prostate volume increase in BPH patients, causing clinical manifestations that interfere with and reduce the quality of life of patients.

There are several limitations to this study. First, we evaluated PSA and prostate volume-based only on medical record data. Therefore, our sample size depends on the completeness of the data written in the medical record. Second, prostate parameter data is only taken at one time.
The best way to monitor the prostate growth pattern would be to perform a longitudinal study, where all of the participants could be measured and followed for several years in order to obtain an accurate growth rate (Zhang et al., 2013). Longitudinal research in the future is expected to complement the results of this cross-sectional study.

\section{CONCLUSION}

In conclusion, serum PSA levels have a strong relationship with prostate volume in $\mathrm{BPH}$ patients. The average serum PSA level and prostate volume obtained in this study are slightly different from studies that have been done in several other areas before. The researcher suggests that further research be conducted on $\mathrm{BPH}$ in Indonesia.

\section{REFERENCES}

Al-Khalil, S., Boothe, D., Durdin, T., Sunkara, S., Watkins, P., Yang, S., ... de Riese, W. (2016). Interactions between benign prostatic hyperplasia $(\mathrm{BPH})$ and prostate cancer in large prostates: a retrospective data review. International Urology and Nephrology, 48(1), 91-97. https://doi. org/10.1007/s11255-015-1146-2

Deori, R., Das, B., \& Rahman, M. A. (2017). A Study of Relationship of Prostate Volume, Prostate-Specific Antigen and age in Benign Prostatic Hyperplasia. International Journal of Contemporary Medical Research, 4(7), 1582-1586.

Dhingra, N., \& Bhagwat, D. (2011). Benign prostatic hyperplasia: An overview of existing treatment. Indian Journal of Pharmacology. https://doi. org/10.4103/0253-7613.75657

Egan, K. B. (2016). The Epidemiology of Benign Prostatic Hyperplasia Associated with Lower Urinary Tract Symptoms: 
Prevalence and Incident Rates. Urologic Clinics of North America, 43(3), 289-297. https://doi.org/10.1016/j. ucl.2016.04.001

Erdogan, A., Polat, S., Keskin, E., \& Turan, A. (2019). Is prostate volume better than PSA density and free/total PSA ratio in predicting prostate cancer in patients with PSA $2.5-10 \mathrm{ng} / \mathrm{mL}$ and $10.1-30 \mathrm{ng} /$ mL? Aging Male, 0(0), 1-7. https://doi. org/10.1080/13685538.2019.1578741

Haverkamp, K., Harder, L. K., Sophie, N., Kuhnt, M., Lüpke, M., Nolte, I., \& Wefstaedt, P. (2019). Evaluation of canine prostate volume in calculated tomographic images - comparison of two assessment methods. 3, 1-12.

Jung, J. H., Ahn, S. V., Song, J. M., Chang, S., Kim, K. J., Kwon, S. W., \& Park, S. (2016). Obesity as a Risk Factor for Prostatic Enlargement : A Retrospective Cohort Study in Korea. 321-328.

Kapoor, A. (2012). Benign prostatic hyperplasia $(\mathrm{BPH})$ management in the primary care setting. Canadian Journal of Urology.

Kowalkouski, M. A., Goltz, H. H., Hart, S. L., \& Latini, D. (2013). Prostate-Specific Antigen (PSA). In M. D. Gellman \& J. R. Turner (Eds.), Encyclopedia of Behavioral Medicine (pp. 1547-1548). https://doi.org/10.1007/978-1-44191005-9_211

Krisna, D. M., Maulana, A., \& Kresnoadi, E. (2017). Correlation between ProstateSpecific-Antigen (PSA) Level and Prostate Volume in Benign Prostatic Hyperplasia at Bhayangkara Hospital Mataram. Journal of Medicine and Health, 1(6), 525-531.
Lim, K. Bin. (2017). Epidemiology of clinical benign prostatic hyperplasia. Asian Journal of Urology, 4(3), 148-151. https:// doi.org/10.1016/j.ajur.2017.06.004

Liu, J., Tang, J., Gong, D., \& Kong, C. (2017). Level change of prostate-specific antigen in patients with benign prostatic hyperplasia after transurethral prostatic resection. Journal of Integrative Nephrology and Andrology, 4(1), 10. https://doi. org/10.4103/2394-2916.201276

Mao, Q., Zheng, X., Jia, X., Wang, Y., Qin, J., Yang, K., ... Xie, L. (2009). Relationships between total/free prostate-specific antigen and prostate volume in Chinese men with biopsy-proven benign prostatic hyperplasia. International Urology and Nephrology, 41(4), 761-766. https://doi. org/10.1007/s11255-009-9533-1

Mochtar, C. A., Umbas, R., Soebadi, D. M., Rasyid, N., Noegroho, B. S., Poernomo, B. B., ... Hamid, A. R. A. H. (2015). Pedoman Penatalaksanaan Klinis Pembesaran Prostat Jinak (Benign Prostatic Hyperplasia / BPH) (2nd ed.). Jakarta: Ikatan Ahli Urologi, Indonesia.

Patel, N. D., \& Parsons, J. K. (2014). Epidemiology and etiology of benign prostatic hyperplasia and bladder outlet obstruction. Indian Journal of Urology. https://doi.org/10.4103/09701591.126900

Putra, I. B. O. W., Hamid, A. R. A. H., Mochtar, C. A., \& Umbas, R. (2016). Relationship of age, prostate-specific antigen, and prostate volume in Indonesian men with benign prostatic hyperplasia. Prostate International, 4(2), 43-48. https://doi. org/10.1016/j.prnil.2016.03.002

Rybalov, M., Breeuwsma, A. J., Leliveld, A. M., Pruim, J., Dierckx, R. A., \& de Jong, I. J. (2013). Impact of total PSA, 


\section{QANUN MEDIKA}

PSA doubling time, and PSA velocity on detection rates of $11 \mathrm{C}$-Choline positron emission tomography in recurrent prostate cancer. World Journal of Urology, 31(2), 319-323. https://doi.org/10.1007/s00345012-0908-z

Sarma, A. V, Parsons, J. K., Mcvary, K., \& Wei, J. T. (2009). Diabetes and Benign Prostatic Hyperplasia / Lower Urinary Tract Symptoms - What do We Know ? JURO, 182(6), S32-S37. https://doi. org/10.1016/j.juro.2009.07.088

Tang, J., \& Yang, J. (2009). Etiopathogenesis of benign prostatic hyperplasia. Indian Journal of Urology. https://doi. org/10.4103/0970-1591.56179

Zhang, S., Qian, H., Zhao, Y., Sun, K., Wang, H., Liang, G., \& Li, F. (2013). Relationship between age and prostate size. Asian Journal of Andrology, 15(1), 116-120. https://doi.org/10.1038/aja.2012.127 